\title{
CONSIDERING CUSTOMER LOYALTY IN DEVELOPING SERVICE RECOVERY STRATEGIES
}

\author{
Tina L. Robbins \\ \& \\ Janis L. Miller \\ Clemson University \\ Clemson, SC
}

\begin{abstract}
Customer loyalty has been an often suggested and supported consequence of effective service recovery management. We predicted that customer loyalty would also play an antecedent role in the recovery process by interacting with perceived unfairness in influencing subsequent reactions. We found that perceptions of both distributive and procedural fairness in recovery management had more significant influences on reactions by loyal customers. Furthermore, the effectiveness of service recovery had the strongest influence on loyal customers. Implications for service recovery strategies are discussed.
\end{abstract}

Substantial evidence (e.g., Tax \& Brown, 1998) supports the importance of effectiveness in the management of service recovery. Service recovery has been defined (Johnston and Hewa, 1997) as the "actions of a service provider to mitigate and/or repair the damage to a customer that results from the provider's failure to deliver service as it is designed" (p. 467). Examples of failures (Bitner, Booms, \& Tetreault, 1990) include unavailable service, unreasonably slow service and other core service problems (e.g., hotel room not clean, restaurant meal is cold, baggage arrives damaged, etc.). Some studies (see Dubé and Maute [1996] for a review) suggest that over half of brand switching in services is attributable to service failures and poor management of recovery. Given the high costs (e.g., loss of both current and potential customers due to negative communications and poor reputation) associated with poor recovery, managers have begun to take steps to mitigate the negative consequences associated with failures in service firm-customer exchanges.

Much of the research on reactions in exchange relationships points to the importance of perceived fairness by parties to the exchange. A vast amount of literature (see Greenberg [1990] for a review) suggests that perceptions of fairness in exchanges with management are significant predictors of employee workplace attitudes and behaviors. Past research has also established that attitudes about fairness are useful for analyzing and understanding customers' evaluations of services in their exchanges with providers. It has been suggested (Berry, 1995) that customers' perceptions of fairness are inseparable from, and captured in all dimensions of service quality. 
Equity or justice theory has also been used to explain reactions to specific experiences and conflicts in various (e.g., organization-employee, manager-employee, legal authority-citizen, parent-child) exchange relationships (Folger \& Konovsky, 1989; Tyler, 1989; Tyler, 1994). More specifically, this framework has been useful for understanding customer reactions to service failures and subsequent recovery management (e.g., Blodgett, Hill \& Tax, 1997; Hoffman \& Kelley, 2000; Miller, Craighead \& Karwan, 2000; Tax, Brown, \& Chandrashekaran, 1998). Customer perceptions of distributive (outcomes and remedies offered), and procedural (policies used and followed in the process as well as interpersonal treatment of the customer) fairness in recovery management have been found to significantly influence customers' attitudes (trust and commitment) as well as behavioral intentions (repatronage, negative word-of-mouth) following the service failure (e.g., Blodgett, et al., 1997; Tax, et al, 1998).

Customer loyalty has been studied extensively in the management and marketing literatures and its benefits and link to profitability have been well established (see Curasi and Kennedy [2002] and Rundle-Thiele \& Mackay [2001] for reviews). Some studies (e.g., de Ruyter \& Wetzels, 2000; Johnston \& Hewa, 1997; Tax \& Brown, 1998) have analyzed customer loyalty as a consequence of successful service recovery strategies. Our purpose in this study is to analyze the potential for customer loyalty to play an antecedent role in service recovery by interacting with perceptions of unfairness to influence post-failure reactions. Establishing customer loyalty as a significant antecedent to perceptions, attitudes and reactions to service recovery would have important implications for managers in devising strategies that minimize the costs associated with such failures. For example, recovery strategies might need to be contingent on how much the company may lose, given the significant relationship between customer loyalty and profitability (e.g., Reichheld, 1996; Reichheld \& Sasser, 1990; Tax \& Brown, 1998).

\section{Customer Loyalty and Fairness in Service Recovery}

Social psychologists have determined that the processes, perceptions, judgments, and attributions that customers typically use to evaluate services are likely to be influenced by the degree of personalization or the type of relationship between the parties involved (Goodwin \& Gremler, 1996). For example, interviews with both customers and service providers suggest that customer loyalty influences how quality is defined and what type of service delivery is preferred and appropriate. In service exchanges, loyal customers are likely to perceive their relationship with the service provider differently than those who are first-time or very infrequent patrons. Exchange relationships may range from purely economic and transactional in nature to more social, relational or communal (Blau, 1964; Clark \& Mills, 1993; Rousseau \& Parks, 1993).

We believe relationships between loyal customers and service providers are more characteristic of social exchange and loyal customers are more likely to perceive their "psychological" contract with the service provider as relational since trust, loyalty and commitment form the basis for these relationships (Konovsky 
\& Pugh, 1994; Rousseau \& Parks, 1993). With a more relational, as opposed to resource-based motive for justice (Tyler, 1994), loyal customers are likely to place greater emphasis on procedural fairness than non-loyal customers since it is more personal and reflects respect for the relationship. The three relational concerns identified originally by Tyler (1989) and supported in subsequent research (Tyler, 1994; Tyler, Degoey \& Smith, 1996) include 1) standing or status, which refers specifically to politeness and respect for dignity, 2) the neutrality of the decision and 3 ) trust in those third parties to treat people fairly and reasonably.

The intangible or symbolic outcomes of respect and concern that are exhibited with procedural justice may reflect ends in themselves (Folger \& Konovsky, 1989) for loyal customers. On the other hand, customers with lower levels of loyalty should be less interested in the fairness of procedures and interpersonal treatment that form the basis for a longer-term relationship, particularly after experiencing a service failure early in the exchange.

Hypothesis 1: Customer loyalty moderates the relationship between procedural fairness and customer reactions (i.e., change in customer opinion about the company, post-failure loyalty and return intention) to the management of service recovery. Specifically, the positive relationship between procedural fairness and customer reactions will be stronger for more loyal customers.

Customers who have not developed loyalty to the service provider are more likely to perceive their exchange relationship as more short-term, purely economic with lower expectations for fairness beyond the one-time encounter. Past research (see Goodwin \& Gremler [1996] for a review) has shown that non-loyal customers are more influenced by convenience and cost than loyal customers. We believe resource-based models of justice (Tyler, 1994) are more applicable to non-loyal or new customers experiencing a service failure. Those less loyal to the service provider are more likely to be concerned with a fair economic and tangible transaction (e.g., refund, credit, exchange) in the management of service recovery and less concerned about the relational, social elements. In contrast to procedural fairness, a fair outcome is the "typical metric" for judging fairness transactions in economic exchange relationships (Konovsky \& Pugh, 1994). More loyal customers may overlook a single outcome or be willing to forgive what they perceive as an aberrant failure as long as the relational aspects support fairness over time in the exchange (Tyler, 1989). However, less loyal customers are likely to be more concerned with the distributive, rather than the procedural fairness in service recovery management.

Hypothesis 2: Customer loyalty moderates the relationship between distributive fairness and customer reactions (change in opinion of the company, post-failure loyalty and return intention) to the management of service recovery. Specifically the positive relationship between dis- 
tributive fairness and customer reactions will be stronger for less loyal customers.

Customer loyalty is most often considered an asset given its link to profitability (e.g., Hoffman \& Kelley, 2000; Reichheld \& Sasser, 1990) and other general benefits. Customers in a closer relationship with the service provider have a higher volume of business (Reichheld \& Sasser, 1990) are less price sensitive (Reichheld, 1996) and report that they are less likely to consider alternatives or shop for lower prices (e.g., Goodwin \& Gremler, 1996). It seems logical therefore that customer loyalty would temper negative reactions and consequences of service failure. The assimilation effect (Brockner, Tyler \& Cooper-Schneider, 1992) should lead customers to react in a way that is consistent with prior attitudes and in the event of a service failure, give the company the benefit of the doubt. A similar link between agency-client relational bonds and judgments of quality has been proposed (Halinen, 1996) in professional services. Although the findings are quite mixed, there is some evidence to support this relationship. For example, Miller, et al. (2000) found that customer pre-failure loyalty had a positive effect on subsequent perceptions of the problem being solved to his or her satisfaction. Similarly, Tax et al. (1998) found that prior positive experiences with service firms mitigate the negative impact of poor complaint handling on subsequent levels of customer commitment. The successful experiences tend to counterbalance a failure (Boulding, Kalra, Staelin, \& Zeithaml, 1993) for loyal customers.

However, there is also evidence to suggest that customer loyalty may act as a liability in the context of service failures and we believe there are compelling arguments and evidence (e.g., Brockner et al., 1992; Tax \& Brown, 1998) to support this interactive pattern. As proposed earlier, those who are loyal customers are more likely to value the relationship and perceive it as social, with the expectation of being treated fairly in interactions with the other party. These customers expect better or preferential treatment in exchange for their contributions such as continuous, loyal business (Seiders \& Berry, 1998) in order to maintain equity in the relationship (Kelley \& Davis, 1994). When they believe they have been treated unfairly, they are likely to react more negatively than those with less invested (Brockner, et al., 1992) prior to the service failure. In other words, the most damage will occur when expectations for service recovery are high but recovery is poorly managed (Tax et al., 1998). We therefore predict that while well-managed failures may have the most positive influence on loyal customers, the poorly managed failures experienced by loyal customers will lead to the most significant detriment in reactions.

Hypothesis 3: Customer loyalty moderates the relationship between the effectiveness of recovery management and customer reactions (i.e., change in opinion about the company, post-failure customer loyalty and return intention). Specifically, the positive relationship between man- 
agement effectiveness and customer reactions will be stronger for more loyal customers.

\section{Methods}

The Critical Incident Technique (Flanagan, 1954), a method often used in the analysis of service encounters (Bitner, et al., 1990; Bitner, Booms \& Mohr, 1994; Johnston, 1995a; Hoffman, Kelley \& Rotalsky, 1995; Miller, et al., 2000; Youngdahl \& Kellogg, 1997) was used to collect the data for this study. A total of seventy undergraduate students served as subjects and each described and answered both open-ended and multiple-choice survey items about two service failures (critical incidents); for the first failure they described a successful resolution and for the second an unsuccessful resolution. These subjects described the company, the service failure, provided their evaluations of service recovery management and perceptions of the fairness of interactions and outcomes for both incidents. Pre-failure variables (i.e., customer loyalty) as well as post-failure reactions (e.g., loyalty, repatronage intentions, etc.) were also assessed. A subset of the variables measured was used to test the hypotheses in this study.

From this sample we obtained 134 usable responses, 67 resolved and 67 unresolved, from a variety of industries including restaurants (17), mail order/internet sales (16), phone/cable TV services (14), electronics retail and repair (13), airline/hotel/cruise (12) and auto sales/repair (11). Common failures in restaurants were food not prepared and/or delivered as specified, incorrect products delivered or products that didn't meet expectations in mail-order and internet sales, service and billing problems for telephone and cable television companies, products that didn't operate as expected for electronic retail/repair and auto sales/repair, and delays and luggage problems for airline, cruise, and hotel services.

\section{Measures}

Customer lovalty. We used one item to directly inquire about the subjects' degree of loyalty prior to the failure. Specifically, customers were asked their level of agreement (5-point strongly agree to strongly disagree) that they would classify themselves as a loyal customer prior to the service failure. Single-item measures have been used in past research (e.g., Flannery \& May, 2000; Fulk, 1993) and supported as reliable, particularly when measuring attitudes (e.g., Wanous, Reichers \& Hudy, 1997). But we also used a few indirect items to validate and corroborate our findings. These somewhat more objective items measured the length (first time, days, weeks, months or years) and number of times $(0,1,2-4$, $5-19,20$ or more) the subject had used the services prior to the failure. By using reports of actual patronage to back up self-reported loyalty, we were able to assess the subjects' behavioral as well as attitudinal commitment (Curasi \& Kennedy, 2002; Rundle-Thiele \& Mackay, 2001).

Distributive fairness. We used the sum of two items consistent with the literature in this stream of research (e.g., Greenberg, 1990; Hoffman \& Kelley, 2000) to measure perceptions of outcome fairness. One item asked the subject to rate the 
outcomes of the recovery process on a 5-point scale from very fair to very unfair. The second item assessed the subject's level of agreement (from strongly agree to strongly disagree) that the "outcomes of the solution process were appropriate." Appropriateness has been used in past research (e.g., Greenberg, 1993) as alternative terminology for assessing fairness perceptions.

Procedural fairness. We measured procedural fairness with the sum of three items based on prior operationalizations of this construct as dependent not only on the perceived fairness of the process, but also on the interpersonal behavior of those making the decision or those in positions of authority (e.g., Brockner \& Weisenfeld, 1996). This operationalization is consistent with the group-value model of procedural justice, which suggests that identity-relevant information is communicated by the fairness of procedures and treatment (Tyler, et al., 1996). One item tapped the subject's perception of the fairness of the solution process and another the fairness of the personal treatment received during the process. A 5-point scale that ranged from very fair to very unfair was used for responses to these items. The other item measured the subject's level of agreement (from strongly agree to strongly disagree) that "the company was open and honest" during the solution process".

Effectiveness of service recovery management. Customer evaluations of service recovery efforts were measured as the sum of two items, one that assessed the degree to which the subject felt the problem was solved fairly and the other the degree to which the company solved the problem to his or her satisfaction. Customer satisfaction and perceived fairness have been the standards for evaluating the effectiveness of service recovery in this stream of research (e.g., Goodwin \& Ross, 1992; Hoffman \& Kelley, 2000; Kelley \& Davis, 1994). The 5-point scale from very fair to very unfair was used for the first item and the 5-points from strongly agree to strongly disagree was used for the second item.

Reactions to service recovery management. Customer reactions to service recovery efforts included the customer's change in opinion of the company following service recovery, post-failure loyalty toward the company, as well as repatronage intentions. Customers were asked the degree (using the 5-point strongly agree to strongly disagree scale) to which they would classify themselves as a loyal customer and the degree to which their opinion had changed because of the management of recovery. Repatronage intentions were assessed using a 5 -point scale that ranged from "already have gone back to the company" to "being certain of never returning".

\section{Data Analysis}

Means, standard deviations and correlations for all variables are shown in Table 1. A confirmatory factor analysis was conducted and all indicator variables loaded significantly $(\mathrm{p}<.01)$ on the hypothesized factors. The loadings ranged from .82 to .98 and the analysis supported the fit $(\mathrm{CFI}=.98, \mathrm{NFI}=.96, \mathrm{RMSR}=.03)$ of the five-factor model. The Cronbach's alpha coefficients, also shown in Table 1, provide strong support for the reliability of these measures as well. 
Table 1

Means, Standard Deviations, Reliabilities and Correlations for All Variables

\begin{tabular}{|c|c|c|c|c|c|c|c|c|}
\hline Variable & $\mathbf{n}$ & Mean & s.d. & 1 & 2 & 3 & 4 & 5 \\
\hline 1. Customer Loyalty & 133 & 3.71 & 0.94 & - & & & & \\
\hline 2. Distributive Fairness & 133 & 6.47 & 3.03 & $0.25^{* *}$ & 0.97 & & & \\
\hline 3. Procedural Fairness & 132 & 9.66 & 4.26 & $0.22^{*}$ & $0.92^{* *}$ & 0.93 & & \\
\hline $\begin{array}{l}\text { 4. Effectiveness of } \\
\text { service recovery management }\end{array}$ & 134 & 6.11 & 3.15 & $0.20^{*}$ & $0.93^{* *}$ & $0.92 * *$ & 0.98 & \\
\hline $\begin{array}{l}\text { 5. Reactions to } \\
\text { service recovery management }\end{array}$ & 132 & 8.63 & 3.72 & $0.36^{* *}$ & $0.83^{* *}$ & $0.86^{* *}$ & $0.85^{* *}$ & 0.92 \\
\hline
\end{tabular}

one-tailed tes

$* * 0<.01$, one-tailed test

alpha coefficients on the diagonal 
The three hypotheses were tested using linear regression with three independent variables: the independent variable of interest, customer loyalty and the interaction between loyalty and the first independent variable. To minimize multicollinearity between the predictor variables and the interactions, all variables were transformed to center the scales at zero by subtracting the mean (Aiken \& West, 1991). When we found a significant interaction, we plotted the relationship between the independent and dependent variable at three levels of loyalty as suggested by Aiken and West (1991): loyalty at one standard deviation below the mean, loyalty at the mean and loyalty at one standard deviation above the mean.

\section{Results}

We analyzed Hypothesis I with the use of procedural fairness, customer loyalty, and the interaction of the two as predictors of customer reactions to service recovery management. The regression model was significant $\left(R^{2}=.77, F=140\right.$, $p<.01)$. Main effects for both procedural fairness $(b=.72, t=18.67, p<.01)$ and loyalty ( $b=.80, t=4.44, p<.01$ ) support the direct importance of these variables in the management of service recovery. More relevant to our prediction is the marginally significant $(b=.06, t=1.81, p<.10)$ interaction between customer loyalty and procedural fairness which lends moderate support for Hypothesis 1. The nature of this interaction, illustrated in Figure 1, is also consistent with Hypothesis 1 in that the influence of procedural justice on reactions to service recovery management was strongest for the most loyal customers.

\section{Figure 1 \\ Interactions Results}

Hypothesis 1

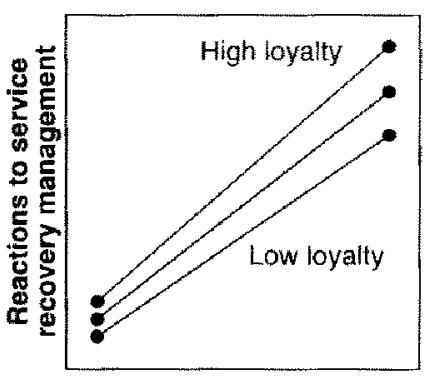

Interactional fairness
Hypothesis 2

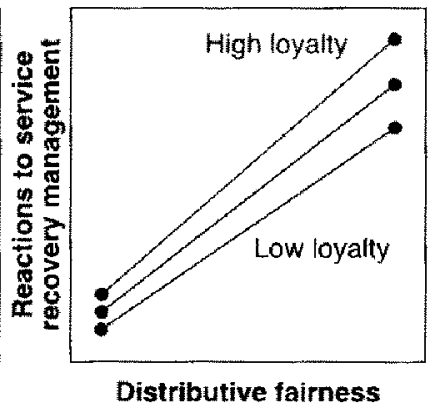

Hypothesis 3

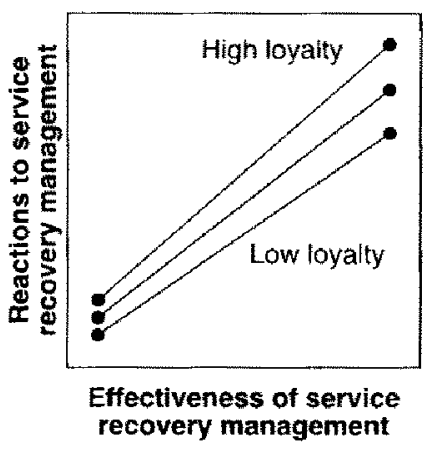

Although the interaction between procedural and distributive justice was not a main focus in this research, we included interactions between the two as well as each with loyalty in an analysis predicting reactions to service recovery. Unlike the pattern prevalent in past organizational justice research (e.g., Brockner \& Wiesenfeld, 1996), there were no significant interactions between distributive and 
procedural justice in the context addressed by our research (i.e., the management of service failures and recovery).

Hypothesis 2 was tested with the use of distributive fairness, customer loyalty and the interaction of the two in predicting customer reactions to the management of service recovery. This model was also significant $\left(R^{2}=.72, F=110\right.$, $p<.01)$ and main effects for distributive fairness $(b=.98, t=16.49, p<.01)$ and loyalty $(b=.74, t=3.67, p<.01)$ suggest a direct influence of these variables on customer reactions to service recovery management. The marginally significant ( $b=.10, t=1.88, p<.10$ ) interaction between distributive fairness and customer loyalty provides modest support for Hypothesis 2. However, in contrast to our specific prediction (and as shown in Figure 1), the strongest relationship between distributive fairness and customer reactions was found for the most loyal, rather than the least loyal customers.

In order to analyze Hypothesis 3 , effectiveness of service recovery management, customer loyalty, as well as the interaction of the two, were used as predictors of customer reactions. The resulting regression model was significant $\left(R^{2}=.77\right.$, $F=144, p<.01)$ as were main effects for both loyalty $(b=.89, t=5.04, p<.01)$ and effectiveness of recovery management $(b=.97, t=18.89, p<.01)$. More importantly, support for Hypothesis 3 was indicated by a significant interaction $(b=.10, t=2.08, p<.05$ ) between customer loyalty and effectiveness of service recovery management in predicting customer reactions. Figure 1 illustrates the nature of the interaction that supports Hypothesis 3. Loyal customers were the most strongly affected by how the service recovery was handled.

The results above reflect the findings when the use of the single-item attitudinal measure of loyalty, described earlier, was used in the analyses. When the two behavioral measures of loyalty were used, the findings were consistent with respect to the hypotheses, but resulted in stronger statistical support for the interactions between both procedural and distributive fairness with loyalty.

\section{Discussion}

The results of this study support an important antecedent role for customer loyalty in the management of service recovery. Both procedural and distributive fairness in recovery had stronger influences on subsequent reactions of customers with higher levels of loyalty prior to the service failure. Satisfaction of customers is dependent on the degree to which managers of services are aware of, and can meet the conditions of the psychological contracts they hold with the business (Clemmer \& Schneider, 1996). A first step toward meeting those contracts is to understand the differences and expectations that vary with customer loyalty. Perhaps recovery management is more significant for loyal customers because of higher expectations (Kelley \& Davis, 1994). Loyal customers expect some special treatment and do not want to be "treated as a number" (Goodwin \& Gremler, 1996; Kelley \& Davis, 1994).

It appears that both procedural and distributive fairness are more significant components of the exchange relationship for loyal customers. Loyal customers 
may perceive their psychological contracts as more relational (than transactiona) however while socio-emotional and intrinsic elements are of greater importance with this type of implied contract, there is still an economic focus in this type of exchange (Rousseau \& Parks, 1993). Finding the same pattern of results with respect to both types of fairness may be attributable to the positive association between distributive and procedural justice in the context of service failures and recovery attempts. Customers are more likely to perceive outcomes such as monetary funds, credits, etc., as fair if they are treated fairly and respectfully in interactions with managers and employees (see Blodgett, et al. [1997] and Tax, et al. [1998] for reviews). On the other hand, when procedural justice is low, outcomes are also likely to be perceived as unfair. Past research (Brockner \& Weisenfeld, 1996) suggests that in the case of procedural unfairness, individuals may redefine what was once a relational exchange, as more "businesslike". As with unfair procedures (Brockner \& Wiesenfeld, 1996), the service failure itself may threaten the individual's self-esteem and change the element of group identification, in which case material outcomes become more important (Brockner \& Wiesenfeld, 1996).

The findings of this study suggest that the group-value model (e.g., Tyler, 1989), used to explain reactions to justice perceptions in other types of exchanges (e.g., manager-employee), has potential for explaining the dynamics of the customer-service firm relationship. Our findings are consistent with the group-value motive, in that those most committed to an institution care more about relational/procedural concerns (Tyler, 1989). Loyal customers are likely more concerned with their long-term relationship with the service firm, as assumed by the group-value motive for justice, which emphasizes the importance of social interactions that provide emotional support and a sense of belonging (Tyler, 1989).

Also consistent with previous interpretations of the group-value motive, is the finding that the most loyal customers, even though they had the most positive reactions overall in this study, reacted most negatively when treated unfairly. "According to the group-value model, those who are more committed to the organization or institution beforehand have invested more of their sense of self-worth in their identification with the group" (Brockner, et al., 1992, p. 243). Unfair treatment is likely to have a particularly detrimental effect for loyal customers, because of their investments with commitment, frequency of patronage, etc. As Brockner et al. (1992) explain, these individuals "had the most to lose".

While organizations are beginning to pursue various service recovery strategies, there have been no specific suggestions, to our knowledge, that customer loyalty should play a role in the management of procedures and outcomes during service recovery. The results of this study suggest that business strategies and training programs should stress the importance of managing the fairness perceptions of loyal customers in particular. Perhaps policies that empower employees during service recovery (e.g., Tax $\&$ Brown, 1998) should specifically allow employees to employ the full range of remedies when loyal customers experience a service failure. Loyal customers should be treated with utmost respect and managers 
should take time to explain decisions leading to the outcomes of service recovery. Unlike when responding to reported problems of non-loyal, problem customers or repeat complainers, the benefits of very liberal outcomes such as full refunds and guarantees (Blodgett, et al., 1997) are most likely to outweigh the costs when provided to loyal customers. This is particularly true given that retaining loyal customers is often a more efficient strategy than pursuing new customers (Hoffman \& Kelley, 2000).

Of course there are some limitations in this study. Some might question the use of students as subjects in this research. However students are customers and their reactions to service failures are therefore comparable to other subject populations (e.g., Greenberg, 1987). The use of a questionnaire for gathering all the data makes the analyses subject to common method variance. Unfortunately, studies (e.g., Clemmer \& Schneider, 1996; Miller et al., 2000; Tyler, 1994) addressing perceptions of fairness in actual experiences with authorities and services providers have been prone to common method variance. But unlike many studies (e.g., Blodgett, et al., 1997; de Ruyter \& Wetzels, 2000; Goodwin \& Ross, 1992; Kelley \& Davis, 1994) that have analyzed hypothetical and experimental scenarios, we used actual experiences with service failure and recovery. Given the potential ethical and practical problems with conducting a field experiment of this nature (de Ruyter \& Wetzels, 2000) and the lack of external validity with the use of hypothetical scenarios, we felt the Critical Incident Technique, although associated with the use of common methods, to be a good compromise as well as a complement to much of the earlier work on reactions to service failure and recovery management.

Cross-sectional data also preclude interpretations of causality although some of the more objective items measuring customer loyalty (i.e., actual patronage behavior prior to the service failure) should ensure temporal order on the part of this main predictor of interest. Nonetheless, future research that employs different and/or longitudinal methods when analyzing antecedents and consequences of service recovery attempts would help to corroborate these findings.

We aimed to more thoroughly develop the theoretical bases for our predictions and interpretations in order to address the lack of conceptual understanding in the management of service recovery (Blodgett, et al., 1997; Kelley \& Davis, 1994). Our findings suggest that much of the theory on the role of fairness in other types of exchanges may be useful for understanding the justice motive in customer-service firm relationships. Future research should attempt to directly measure variables associated with these conceptual underpinnings (perceived contracts, expectations, group-value motives) to confirm their validity for understanding the relationships. Future research should also analyze customer loyalty as a potential common link among previously suggested (see de Ruyter \& Wetzels [2000] for a review) contingencies of perceptions and reactions to service failure and recovery management: the seriousness of the service failure (Kelley, Davis \& Hoffman, 1993), whether the customer feels annoyed or victimized (Johnston, 1995b), and customer equity sensitivity (Oliver, 1997). 
Because of their commitment and investment, loyal customers are likely to feel entitled to more than what is equitable (e.g., Huseman, Hatfield \& Miles, 1987). These customers may feel they are owed more because of their loyalty and are therefore more likely to perceive an unsuccessful recovery as serious and feel victimized by it.

Given the substantial benefits of effective recovery (e.g., Hoffman \& Kelley, 2000; Tax \& Brown, 1998), any practical way to improve management in the event of a service failure should have significant implications for the organization. Business strategies that maximize these benefits while also exploiting the retention-loyalty-profitability linkage should have significant returns for the service firms. To this end, when developing recovery strategies, managers should pay particular attention to ensuring perceptions of fairness in the event that failures are experienced by loyal customers.

\section{References}

Aiken, L., \& West, S. (1991). Multiple regression: Testing and interpreting interactions. Newbury Park, CA: Sage.

Berry, L.L. (1995). On great service: A framework for action. New York: Free Press.

Bitner, M.J., Booms, B.H., \& Mohr, L.A. (1994). Critical service encounters: the employee's viewpoint. Journal of Marketing: 58(4), 95-106.

Bitner, M.J., Booms, B.H., \& Tetreault, M.S. (1990). The service encounter: Diagnosing favorable and unfavorable incidents. Journal of Marketing, 54, 71-84.

Blau, P. (1964). Exchange and power in social life. New York: Wiley.

Blodgett, J.G., Hill, D.J., \& Tax, S.S. (1997). The effects of distributive, procedural, and interactional justice on postcomplaint behavior. Journal of Retailing, 73(2), 185-210.

Boulding, W., Kalra, A., Staelin, R., \& Zeithaml, V.A. (1993). A dynamic process model of service quality: From expectations to behavioral intentions. Journal of Marketing Research, 30, 7-27.

Brockner, J., \& Wiesenfeld, B.M. (1996). An integrative framework for explaining reactions to decisions: Interactive effects of outcomes and procedures. Psychological Bulletin, 120, 189-208.

Brockner, J., Tyler, R., \& Cooper-Schneider, R. (1992). The influence of prior commitment to an institution on reactions to perceived unfairness: The higher they are, they harder they fall. Administrative Science Quarterly, 37, 241-261.

Clark, M.S., \& Mills, J. (1993). The difference between communal and exchange relationships: What it is and is not. Personality and Social Psychology Bulletin, 19, 684-691. 
Clemmer, E.C., \& Schneider, B. (1996). Fair service. In T. Swartz, D. Bowen, \& S. Brown (Eds.) Advances in services marketing and management (pp. 109-126). Greenwich, CT: JAI Press.

Curasi, C.F., \& Kennedy, K.M. (2002). From prisoners to apostles: A typology of repeat buyers and loyal customers in service businesses. Journal of Services Marketing. 16(4), 322-341.

de Ruyter, K., \& Wetzels, M. (2000). Customer equity considerations in service recovery: A cross-industry perspective. International Journal of Service Industry Management, 11, 91-108.

Dubé, L., \& Maute, M. (1996). The antecedents of brand switching, brand loyalty and verbal responses to service failure. Advances in Services Marketing and Management. $5,127-151$.

Flanagan, J.C. (1954). The critical incident technique. Psychological Bulletin, 51, $327-359$.

Flannery, B.L., \& May, D.R. (2000). Environmental ethical decision making in the U.S. metal-finishing industry. Academy of Management Journal, 43, 642-662.

Folger, R., \& Konovsky, M.A. (1989). Effects of procedural and distributive justice on reactions to pay raise decisions. Academy of Management Journal, 32, 115-130.

Fulk, J. (1993). Social construction of communication technology. Academy of Management Journal, 36, $921-950$.

Goodwin, C., \& Gremler, D.D. (1996). Friendship over the counter: How social aspects of the service encounters influence consumer service loyalty. Advances in Services Marketing and Management, 5, 247-282.

Goodwin, C., \& Ross, 1. (1992). Consumer responses to service failures: Influence of procedural and interactional fairness perceptions. Journal of Business Research, 25(2), 149-163.

Greenberg, J. (1987). The college sophomore as guinea pig: Setting the record straight. Academy of Management Review, 12, 157-159.

Greenberg, J. (1990). Organizational justice: Yesterday, today and tomorrow. Journal of Management, 16, 399-432.

Greenberg, J. (1993). Stealing in the name of justice: Informational and interpersonal moderators of theft reactions to underpayment inequity. Organizational Behavior and Human Decision Processes, 54, 81-103.

Halinen, A. (1996). Service quality in professional services: A relationship approach. Advances in Services Marketing and Management, 5, 315-341. 
Hoffman, K.D., \& Kelley, S.W. (2000). Perceived justice needs and recovery evaluation: A contingency approach. European Journal of Marketing, 34, 418-432.

Hoffman, K.D., Kelley, S.W., \& Rotalsky, H.M. (1995). Tracking service failures and employee recovery efforts. Journal of Services Marketing, 9(2), 49-61.

Huseman, R.C., Hatfield, J.D., \& Miles, E.W. (1985). A new perspective on equity theory: The equity sensitivity construct. Academy of Management Review, 12, 222-234.

Johnston, R. (1995a). The determinants of service quality: Satisfiers and dissatisfiers. International Journal of Service Industry Management 6(5), 53-71.

Johnston, R. (1995b). Service failure and recovery: Impact, attributes and process. Advances in Services Marketing and Management, 6(2), 46-61.

Johnston, T.C., \& Hewa, M.A. (1997). Fixing service failures. Industrial Marketing Management, 26, 467-473.

Kelley, S.W., \& Davis, M.A. (1994). Antecedents to customer expectations for service recovery. Journal of the Academy of Marketing Science, 22, 52-61.

Kelley, S.W., Davis, M.A., \& Hoffman, K.D. (1993). A typology of retail failures and recoveries. Journal of Retailing, 69(4), 429-452.

Konovsky, M.A., \& Pugh, S.D. (1994). Citizenship behavior and social exchange. Academy of Management Journal, 37, 656-669.

Miller, J.L., Craighead, C.W., \& Karwan, K.R. (2000). Service recovery: A framework and empirical investigation. Journal of Operations Management, 18, 387-400.

Oliver, R.L. (1997). Satisfaction, a behavioral perspective on the consumer. McGraw-Hill, New York, NY.

Reichheld, F.F. (1996). The loyalty effect. Boston, MA: Harvard Business School Press.

Reichheld, F.F., \& Sasser, W.E. (1990, September-October). Zero defections: Quality comes to service. Harvard Business Review, 68, 105-111.

Rousseau, D.M., \& Parks, J.M. (1993). The contracts of individuals and organizations. In L.L. Cummings \& B. Staw (Eds.), Research in Organizational Behavior, 15 (pp. 1-47). Greenwich, CT: JAI Press.

Rundle-Thiele, S., \& Mackay, M.M. (2001). Assessing the performance of brand loyalty measures. Journal of Services Marketing, 15, 529-546.

Seiders, K., \& Berry, L.L. (1998). Service fairness: What is it and why it matters. Academy of Management Executive, 12, 8-20. 
Tax, S.S., \& Brown, S.W. (1998, Fall). Recovering and learning from service failure. Sloan Management Review, 40, 75-88.

Tax, S.S., Brown, S.W., \& Chandrashekaran, M. (1998). Customer evaluations of service complaint experiences: Implications for relationship marketing. Journal of Marketing. 62, 60-67.

Tyler, T.R. (1989). The psychology of procedural justice: A test of the group-value model. Journal of Personality and Social Psychology, 57, 830-838.

Tyler, T.R. (1994). Psychological models of the justice motive: Antecedents of distributive and procedural justice. Journal of Personality and Social Psychology, 67, 850-863.

Tyler, T., Degoey, P., \& Smith, H. (1996). Understanding why the justice of group procedures matters: A test of the psychological dynamics of the group-value model. Journal of Personality and Social Psychology, 70, 913-930.

Wanous, J., Weichers, A.E., \& Hudy, M.J. (1997). Overall job satisfaction: How good are single item measures? Journal of Applied Psychology, 82, 247-252.

Youngdahl, W.E., \& Kellogg, D.L. (1997). The relationship between service customers' quality assurance behaviors, satisfaction, and effort: A cost of quality perspective. Journal of Operations Management, 15, 19-32.

Tina Robbins is an Associate Professor in the Department of Management, College of Business and Behavioral Sciences at Clemson University, where she teaches organizational behavior. She received her Ph.D. in Business Administration from the University of South Carolina. She has published in the Journal of Applied Psychology, Journal of Management and Human Relations. Her current research interest is organizational justice. She is currently serving on the editorial review board for the Academy of Management Journal.

Janis Miller is an Associate Professor in the Department of Management, College of Business and Behavioral Sciences at Clemson University, where she teaches Service Operations, management science and statistics. She received her Ph.D. in Business Administration from the University of Missouri - Columbia. Much of her recent work has been in the area of service recovery. Her papers have appeared in the Journal of Operations Management, Academy of Management Journal and Operations Research. 
Fall 2004

Robbins \& Miller: Considering Customer Loyalty 